\title{
23-Year-Old Female with an Inflammatory Myofibroblastic Tumour of the Breast: A Case Report and a Review of the Literature
}

\section{3-jährige Patientin mit inflammatorischem myofibroblastischen Tumor der linken Mamma - Fallbeschreibung und Literaturübersicht}

Authors

Affiliations
K. Bosse ${ }^{1}$, C. Ott ${ }^{1}$, T. Biegner ${ }^{2}$, F. Fend ${ }^{2}$, K. Siegmann-Luz ${ }^{3}$, D. Wallwiener ${ }^{1}$, M. Hahn ${ }^{1}$

Department of Obstetrics and Gynecology, University Hospital of Tübingen, Tübingen

${ }^{2}$ Institute of Pathology and Neuropathology, University Hospital of Tübingen, Tübingen

${ }^{3}$ University Hospital of Tuebingen, Diagnostic and Interventional Radiology, Tübingen
Key words

- breast tumor

- inflammatory myofibroblastic tumor

- ALK gene

Schlüsselwörter

- Brusttumor

- inflammatorischer

myofibroblastischer Tumor (IMT)

- ALK-Gen

\section{received 18.9.2013 \\ revised 1.12 .2013 \\ accepted $\quad 3.12 .2013$}

\section{Bibliography}

DOI http://dx.doi.org/ 10.1055/s-0033-1360185

Geburtsh Frauenheilk 2014; 74: 167-170 @ Georg Thieme

Verlag KG Stuttgart · New York · ISSN 0016-5751

\section{Correspondence}

Dr. Kristin Bosse

University Hospital of Tübingen

Department of Obstetrics

and Gynecology

Calwerstraße 7

72076 Tübingen

kristin.bosse@

med.uni-tuebingen.de

\section{Abstract}

$\nabla$

Purpose: Inflammatory myofibroblastic tumours (IMT) are a subcategory of inflammatory pseudotumours (IPT). They arise most commonly in the abdominopelvic region, lung and retroperitoneum, but virtually any anatomical site may be involved. Predominantly children and adolescents are affected and there is a tendency for local recurrence. In the literature up to the present, 20 patients have been reported with an IPT/IMT of the breast. We would like to present another patient with this unusual tumour entity of the breast and discuss the literature.

Patient and Examinations: A 23-year-old woman presented with a painless lump in her left breast. There was no history of breast cancer in her family. Sonography showed a hypoechoic heterogeneous solid mass with irregular margins. A core needle biopsy revealed a tumour of high cellularity and a densely collagenous background. Immunohistochemically, the spindle-shaped cells were immunoreactive to smooth muscle actin and ALK-1 protein. Additional FISH analysis proved ALK rearrangements on chromosome 2p23 leading to the diagnosis of an IMT. Wide surgical excision was performed with no evidence of local recurrence after 12 months.

Conclusion: Three of the above mentioned 20 patients with IMT/IPT of the breast developed a recurrent tumour, none presented with distant metastasis. A significant recurrence rate of $15 \%$ leads to a clinically and sonographically close follow-up in these patients.

\section{Zusammenfassung \\ $\nabla$}

Hintergrund: Inflammatorische myofibroblastische Tumoren (IMT) sind eine Untergruppe der inflammatorischen Pseudotumoren (IPT). Sie entstehen typischerweise in der Lunge und betreffen Kinder oder junge Erwachsene. IMT weisen ein intermediäres biologisches Potenzial auf mit der Neigung zu Lokalrezidiven in bis zu 25\% der Fälle und einem geringen Fernmetastasierungsrisiko. Bis dato sind 20 Patientinnen mit einem IMT der Brust beschrieben. Bei allen bestand die Therapie in der lokalen Exzision. Im Folgenden möchten wir von einer weiteren Patientin mit dieser für die Brust ungewöhnlichen Tumorentität berichten.

Patientin und Untersuchungsbefunde: Eine 23Jährige stellte sich mit einem palpablen ca. $2 \mathrm{~cm}$ großen Tastbefund der linken Brust zur Abklärung vor. Die Familienanamnese ist leer im Hinblick auf Brustkrebs. Sonografie und MRT zeigten eine unscharf begrenzte, suspekte Raumforderung. Es erfolgte die sonografisch gesteuerte Stanzbiopsie. Histologisch ergab sich ein gefäßarmer Tumor mit Proliferaten aus Myo- und Fibroblasten. Immunhistochemisch ließ sich eine mäßiggradige Positivität für ALK (anaplastische Lymphom-Kinase) nachweisen. Mittels Fluoreszenz-in-situ-Hybridisierung (FISH) erfolgte der Nachweis einer Translokation im ALK-Gen Chromosom 2p23 mit Diagnosestellung eines IMT (B3-Läsion). Der Tumor wurde in toto reseziert.

Diskussion: Circa 50\% der IMTs weisen eine Translokation im ALK-Gen auf. Die Positivität scheint nicht mit einem erhöhten Rezidivrisiko zu korrelieren. Drei der eingangs genannten 20 Patientinnen mit IMT der Brust entwickelten in der Nachbeobachtungsperiode ein Lokalrezidiv (15\%), sodass ein engmaschiges Follow-up unserer Patientin sinnvoll ist. 


\section{Introduction}

$\nabla$

Inflammatory myofibroblastic tumours (IMT) are inflammatory pseudotumours (IPT). The latter is a generic term to describe various neoplastic and non-neoplastic entities that share a common histological appearance. Cytologically, this consists of bland spindle cell proliferation with a prominent, usually chronic inflammatory infiltrate [1]. Over the last two decades, IMT has emerged as a distinctive neoplasm of intermediate biological potential [2]. They arise most commonly in the abdominopelvic region, lung and retroperitoneum, but virtually any anatomical location can be involved. Accompanying symptoms can be fever, weight loss and pain as well as anaemia, thrombocytosis and polyclonal hypergammaglobulinaemia. Predominantly children and adolescents are affected but it may appear in either sex at any age. Local recurrence rate varies between $<2$ and $25 \%$ depending on whether the tumour is confined to the lung or an extrapulmonal lesion. Up to the present time 20 patients have been described with an IMT/IPT of the breast ( Table 1 ). All these cases occurred spontaneously without any apparent prior injury. The first case of a posttraumatic IPT has recently been reported by Vecchio et al. in a 22-year-old male [3]. We present another female patient with this unusual tumour entity of the breast and discuss the unique appearance and clinical behaviour of IMTs among the group of spindle-cell breast lesions.

\section{Patient and Examinations}

$\nabla$

A 23-year-old healthy female was examined because of a painless lump in her left upper breast. There was no history of breast cancer in her family. Physical examination revealed a solitary, hard, non-mobile mass measuring approximately $2.0 \mathrm{~cm}$ in size. Lymph nodes were not palpable in the axilla. Sonography showed a hypoechoic heterogeneous lesion of $2.0 \mathrm{~cm}$ in diameter with irregular margins and indifferent acoustic shadowing ( Fig. 1). Power Doppler was negative. Due to the young age of the patient and dense breast tissue we added contrast-enhanced dynamic MR-mammography. MRI confirmed a strong contrast enhancing mass in the left breast corresponding to the ultrasound findings without demonstrating any further lesions (○ Fig. 2). Both imaging modalities were classified as BIRADS IV and a core needle biopsy was performed.

Microscopy showed a well-defined tumour with high cellularity. Histology showed aside from spindle cells that the lesion was composed of a dense mixed inflammatory cell infiltrate of plasma cells and lymphocytes, little cellular atypia and rare mitoses. Immunohistochemistry yielded strong smooth-muscle actin (SMactin) reactivity within the spindle cells with a slight heterogeneous pattern of distribution ( Fig. 3). Other than that the tumour was composed of macrophages intensely expressing CD14

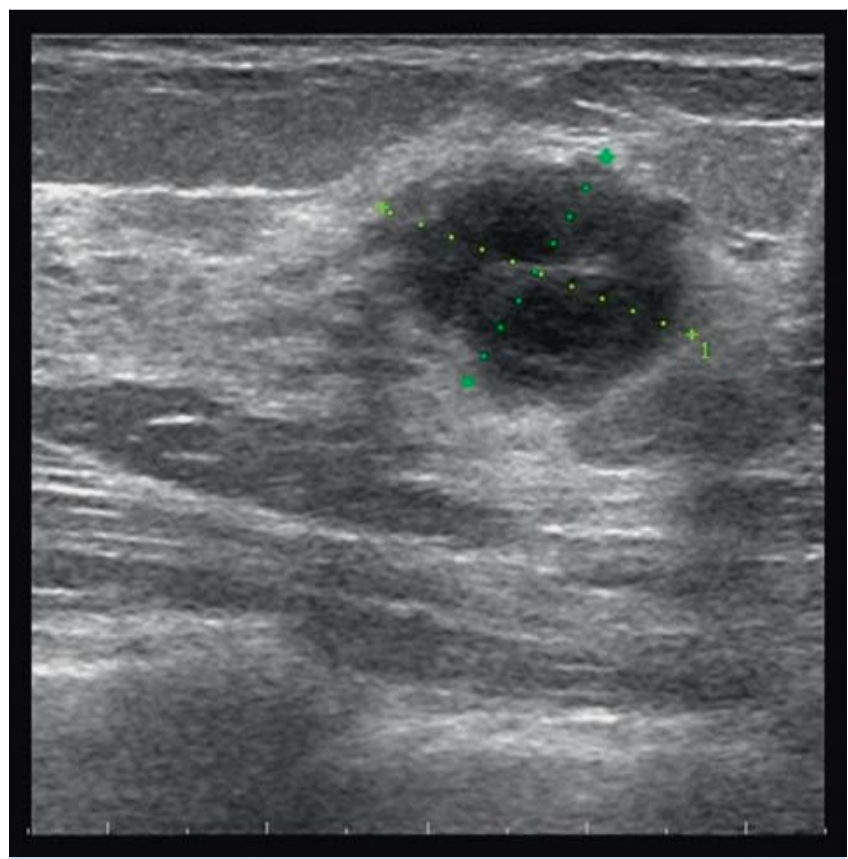

Fig. 1 Sonogramm shows a $2 \mathrm{~cm}$, irregular shaped lesion with indifferent dorsal echoeing.

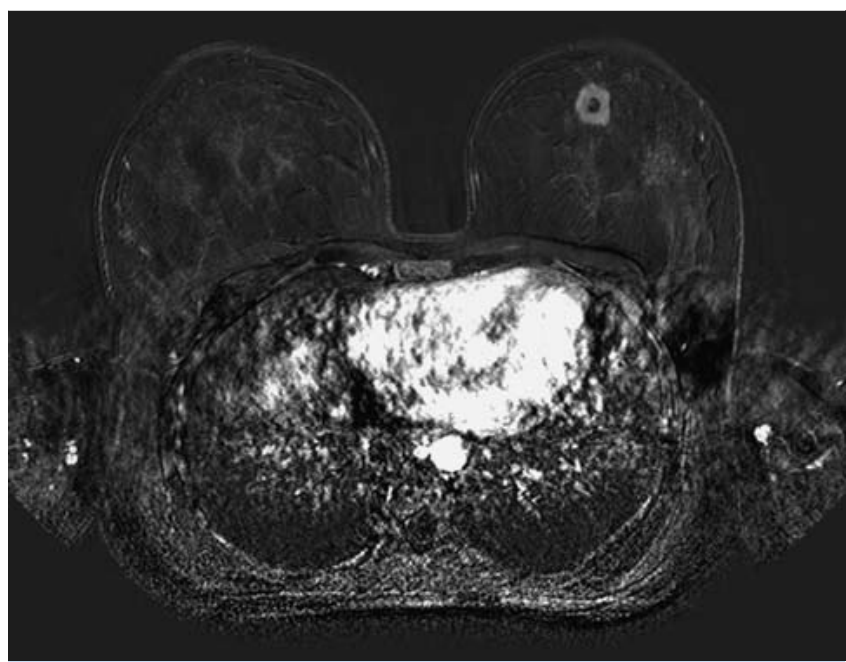

Fig. 2 Subtraction image of T1-weighted contrast-enhanced breast MRI in transverse orientation demonstrating the single nodule in the left upper breast with strong contrast medium enhancement and a central necrosis.

Table 1 IP/IMT in the literature compared to our case; NA, not available.

\begin{tabular}{|c|c|c|c|c|c|}
\hline No. of cases and reference & Age/gender & IP/IMT & ALK positive/negative & Follow-up & Outcome \\
\hline $16[4]$ & range $13-86$ years, female & $7 / 9$ & 5 cases - & maximum 9 years & 3 recurrences \\
\hline $1[5]$ & 60 , female & IMT & - & 24 months & no recurrence \\
\hline $1[6]$ & 53 , female & IMT & - & NA & no recurrence \\
\hline $1[3]$ & 22 , male & IP & - & NA & no recurrence \\
\hline $1[7]$ & 46 , female & IMT & + & 5 years & no recurrence \\
\hline Present case & 23 , female & IMT & + & 12 months & no recurrence \\
\hline
\end{tabular}




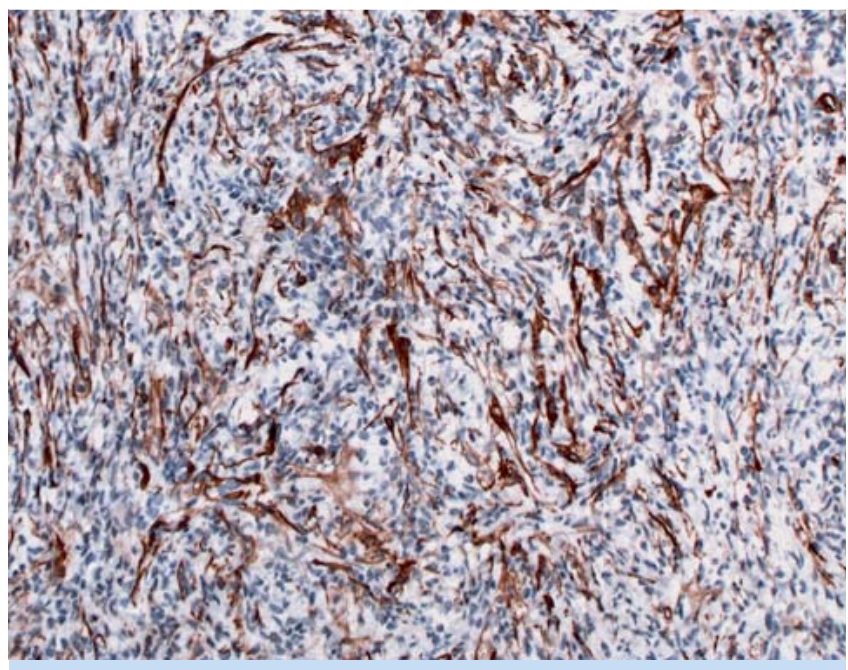

Fig. 3 Positive staining for SM actin.

and CD68 as well as CD3-positive T-lymphocytes with an admixture of scattered CD-20 positive B-lymphocytes. Immunohistochemistry for the pan-cytokeratin markers AE1/3 and E-Cadherin was negative. S100-staining displayed several dendritic cells. Furthermore the ALK protein (anaplastic lymphoma kinase) was moderately positive on staining. FISH analysis using a dual colour probe specific for the ALK gene found a split of the red/green signals, demonstrating rearrangement of this gene on chromosome 2p23 ( Fig. 4). Altogether the findings were consistent with the diagnosis of a myofibroblastic tumour belonging to the category B3 lesions.

The mass was entirely excised with free margins of at least $10 \mathrm{~mm}$ after repeated surgery because of too narrow margins. Macroscopically the nodule was firm, circumscribed and yellow on cut section with a central necrosis ( $\bullet$ Fig. 5).

A survey for distant metastasis including chest x-ray and sonography of the liver showed normal results. The postoperative course was uneventful and the 12-months follow-up examination exhibited no evidence of local recurrence.

\section{Discussion}

\section{$\nabla$}

Inflammatory myofibroblastic tumours of the breast are a very rare condition, which clinically and on imaging easily mimic malignancy [8]. Recommended treatment is complete surgical excision as recurrence rates of up to $25 \%$ are experienced [1]. The World Health Organization continues to classify inflammatory myofibroblastic tumours as a distinct borderline lesion. Still it has not been conclusively decided whether it is reactive or neoplastic in nature. Remarkably, about 50\% of IMTs are positive for rearrangements involving the ALK gene proven by FISH analysis. This property favours the idea of a neoplastic nature of this lesion. Clonal abnormalities of ALK were first described in anaplastic large cell lyphoma (ALCL), which is a true neoplasm [9]. In ALCL patients ALK-positivity is accompanied by a less aggressive clinical course $[10,11]$. Only recently, the first 46-year-old woman with an ALK overexpressing IMT of the breast was reported of [7]. She was free of recurrence five years after diagnosis. Whether there is a more favourable outcome of patients with an ALK-positive IMT is not known yet. Although studies suggest a very low

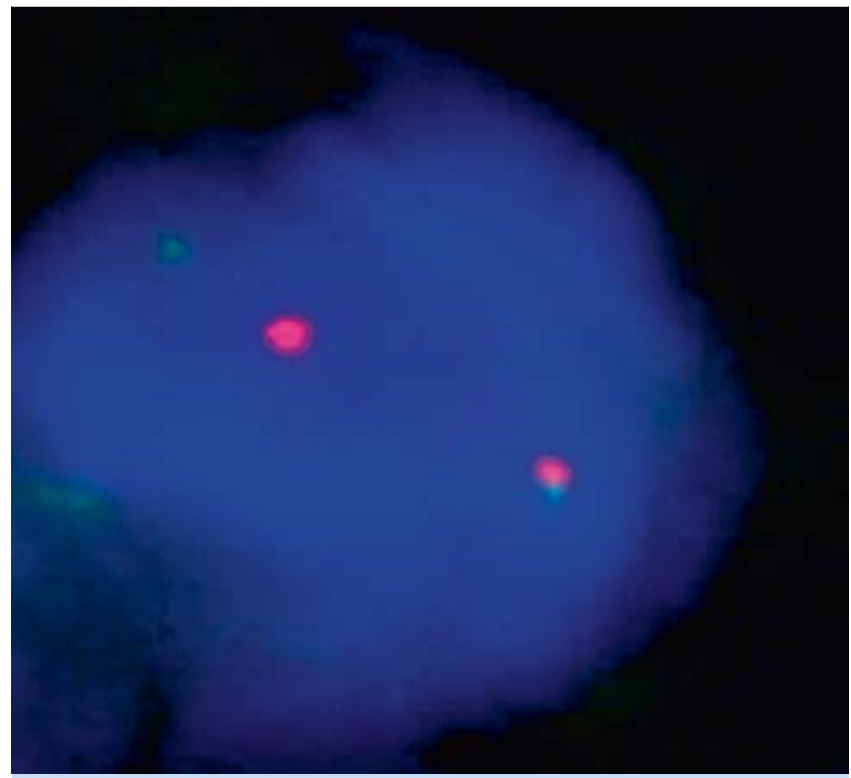

Fig. 4 FISH analysis with two colour probes.

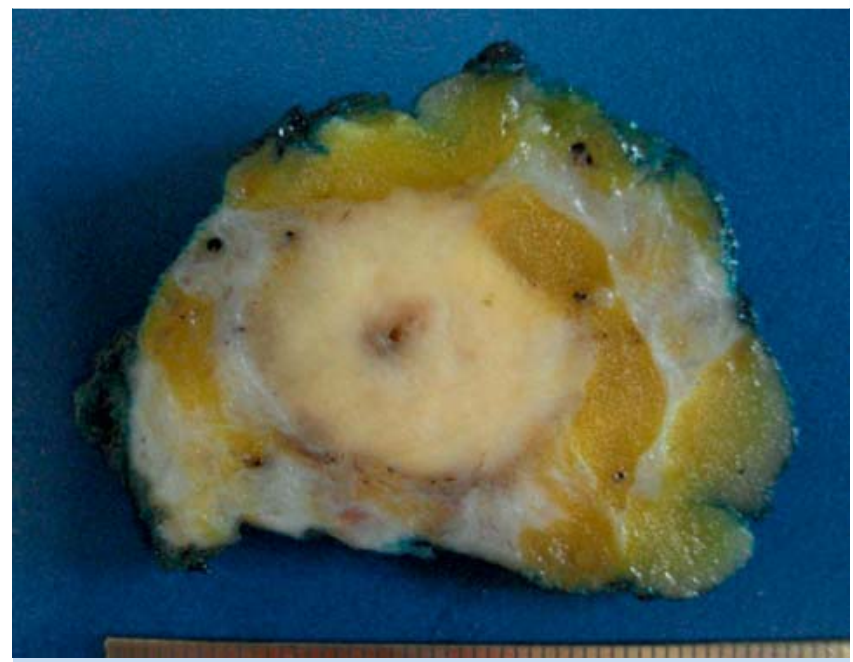

Fig. 5 Macroscopic picture of the well-defined nodule with a central necrosis.

risk for metastasis, its influence on recurrence remains questionable $[12,13]$. Larger numbers of patients with an ALK positive IMT of the breast are needed to judge its impact on metastasis and recurrence. The translocation of the ALK gene leads to a constitutive tyrosine kinase activation. Similar to ALCL, ALK expression is more common in younger patients with IMT, but is not confined to this population. Distant metastasis of IMT is rare, occurring in $<5 \%$ of cases. So far, no patient with an IMT/IPT of the breast has developed distant metastases. But three (15\%) of the 20 reported cases showed local recurrence during follow-up examinations. Time until recurrence varied between three months and nine years. This fact emphasises the need for a close followup in these patients. We recommend sonography every six months as the nodule was well depicted on ultrasound and recurrence rarely developed within months. Mammography is not 
appropriate at this young age. MR-mammography on a regular basis seems overdone.

In summary, according to the literature IMT of the breast is adequately treated with wide local excision. There is no need for radiation and chemotherapy. A survey to exclude distant metastasis is advisable.

\section{Conflict of Interest}

$\nabla$

None.

\section{References}

1 Gleason BC, Hornick JL. Inflammatory myofibroblastic tumours: where are we now? J Clin Pathol 2008; 61: 428-437

2 Coffin CM, Watterson J, Priest JR et al. Extrapulmonary inflammatory myofibroblastic tumor (inflammatory pseudotumor). A clinicopathologic and immunohistochemical study of 84 cases. Am J Surg Pathol 1995; 19: 859-872

3 Vecchio GM, Amico P, Grasso G et al. Post-traumatic inflammatory pseudotumor of the breast with atypical morphological features: a potential diagnostic pitfall. Report of a case and a critical review of the literature. Pathol Res Pract 2011; 207: 322-326

4 Park SB, Kim HH, Shin HJ et al. Inflammatory pseudotumor (myoblastic tumor) of the breast: a case report and review of the literature. J Clin Ultrasound 2010; 38: 52-55
5 Kim SJ, Moon WK, Kim JH et al. Inflammatory pseudotumor of the breast: a case report with imaging findings. Korean J Radiol 2009; 10 : 515-518

6 Hill PA. Inflammatory pseudotumor of the breast: a mimic of breast carcinoma. Breast J 2010; 16: 549-550

7 Zhou Y, Zhu J, Zhang Y et al. An inflammatory myofibroblastic tumour of the breast with ALK overexpression. BMJ Case Rep 2013; DOI: 10.1136/bcr-07-2011-4474

8 Akbulut M, Gunhan-Bilgen I, Zekioglu $O$ et al. Fine needle aspiration cytology of inflammatory myofibroblastic tumour (inflammatory pseudotumour) of the breast: a case report and review of the literature. Cytopathology 2007; 18: 384-387

9 Downing JR, Shurtleff SA, Zielenska $M$ et al. Molecular detection of the $(2 ; 5)$ translocation of non-Hodgkin's lymphoma by reverse transkriptase-polymerase chain reaction. Blood 1995; 85: 3416-3422

10 Falini B, Pileri S, Zinzani PL et al. ALK+ lymphoma: clinico-pathological findings and outcome. Blood 1999; 93: 2697-2706

11 Gascoyne RD, Aoun P, Wu D et al. Prognostic significance of anaplastic lymphoma kinase (ALK) protein expression in adults with anaplastic large cell lymphoma. Blood 1999; 93: 3913-3921

12 Coffin CM, Hornick JL, Fletcher CD. Inflammatory myofibroblastic tumor: comparison of clinicopathologic, histologic, and immunohistochemical features including ALK expression in atypical and aggressive cases. Am J Surg Pathol 2007; 31: 509-520

13 Chun YS, Wang L, Nascimento AG et al. Pediatric inflammatory myofibroblastic tumor: anaplastic lymphoma kinase (ALK) expression and prognosis. Pediatr Blood Cancer 2005; 45: 796-801 